\title{
Temporal variations in the life-cycles of aphids (Sternorrhyncha: Aphididae) and their coccinellid predators
}

\author{
Mohamed El Fodhil AROUN ${ }^{1}$, Bahia DOUMANDJI-MITICHE ${ }^{2}$, DANIEl PETIT $^{3, *}$ and ZAhr-EdDine DJAZOULI ${ }^{1}$ \\ ${ }^{1}$ Department of Plant Biotechnology, Faculty of Nature and Life Sciences, University of Blida I, Blida 0900, Algeria; \\ e-mails:mf_aroun@yahoo.fr; zahro2002@gmail.com \\ ${ }^{2}$ École Nationale Supérieure Agronomique, Hacen Badi, Algiers, Algeria; e-mail: doumandjimitiche@yahoo.fr \\ ${ }^{3}$ UMR 1061, INRA, University of Limoges, 123, av. A. Thomas, 87060 Limoges Cedex, France; e-mail: Daniel.petit@unilim.fr
}

Key words. Sternorrhyncha, Aphididae, aphid, ladybird, life cycle, groups of aphids, coloured basins, abundance, richness, Brevicoryne brassicae, Aphis gossypii, Aphis spiraecola, Hyalopterus pruni

\begin{abstract}
Aphids are either monoecious living either on trees or herbaceous plants, or heteroecious, which involves host alternating between a tree (primary host) and a herbaceous plant (secondary host). We described the temporal variations in abundance and richness of aphids in an Algerian orchard, over a 6 month period. We recorded the choice of basin colour, the relative height of traps, and monthly Barycenter of winged populations. We also recorded temporal variations in the structure of ladybird communities. Tree-living species of aphids are the last to be caught with most caught by the yellow traps, possibly because of the predominant greenness of the vegetation in April. Most were also caught by high traps. Their phenology coincides with that of the second peak of ladybirds. In contrast, the phenology of species of aphids living on herbaceous plants differs greatly, which reflects their host plant diversity. In March relatively more of these aphids were caught by the green traps, possibly because at that time the ground was not yet covered by vegetation. Early and late species of aphids are at greater risk of being attacked by ladybirds as they are also most active early and late in the season. The highest catches of the heteroecious species of aphids were recorded in the middle of the trapping period and between those of the two groups of monoecious species of aphids. The adaptive significance of the differences in the behaviour and ecology of the aphids in the three groups is discussed.
\end{abstract}

\section{INTRODUCTION}

There are about 5000 species of aphids, worldwide (Remaudière \& Remaudière, 1997; Blackman \& Eastop, 1994, 2008, 2012), with over half in the subfamily Aphidinae. Most species of aphid have an annual holocyclic life cycle, which consists of one generation of sexual individuals, followed by several parthenogenetic generations. About $90 \%$ of the species complete their life cycle on the same host plant (= monoecious species) and the remaining 10\% (heteroecious species) alternate between living on a primary host during the cold season and a secondary host in the favourable season. In most cases, the primary host is a tree or shrub and the secondary host an herbaceous plant. In rare cases, not considered here, the heteroecious species host alternate between tree species or between different species of herbaceous plants. The host plant of monoecious species can be a tree, a bush or an herbaceous plant.

Aphids are widely studied, because they are an important threat to agriculture (Blackman \& Eastop, 2012). However, their diverse phenologies and life cycles are still incompletely known, especially for pest aphids in North Africa. Most species of aphids disperse and colonize other plants by means of winged individuals. A common method of monitoring such flights is to use pans or basins of different colours containing soapy water; flying aphids are attracted by the colour of the basins and become trapped in the wa- ter. Interestingly, grass-, tree-foliage- and flower-dwelling insects orient to different colours when flying (Kirk, 1984). The situation in aphids is confusing (Döring \& Chittka, 2007), because foliage colour may be less important than its brightness and contrast with the environment. This is particularly pertinent in the Mediterranean environment in Algeria, where the ground may be bare of herbaceous vegetation at the end of winter, as well as at the end of spring, when the herbaceous vegetation suffers from drought. In Algeria, the periods of drought result in patches of bare ground, which modify the brightness contrast of plants. In addition, aphids fly at different heights, and, thus, the height at which the traps are set is also important. It is hypothesized that monoecious aphids living on trees should fly higher above the ground than monoecious species living on herbaceous plants.

Ladybeetles are important predators of aphids (Ives et al., 1993). Thus, knowledge of coccinellid biology, phenology and flight periods can help in the integrated pest management of aphids. Most aphidophagous Coccinellidae in North Africa have two generations a year (Saharaoui and Hemptinne, 2009), with the first population peak in May (adults and larvae) and a second less abundant one in October (adults and larvae). Thus, some species of ladybirds, in some habitats are rare or absent in summer. In addition, most of the damage done to plants by aphids in North Af-

\footnotetext{
* Corresponding author.
} 
rica occurs in spring and early summer, which is also when most species of aphids disperse. Hence, it appears that the greatest coccinellid activity is synchronized with the period of aphid flight activity, which begins in March and continues to the end of June. Although it is mainly the larval stages of ladybirds that kill the aphids, the sizes of the populations of both adults and larvae of coccinellids vary in parallel (Saharaoui \& Hemptinne, 2009; Mostefaoui et al., 2014). As a consequence, adult coccinellid abundance is a good indicator of the probable abundance of their larvae. A few coccinellid species have more than two generations a year. For example, Coccinella algerica Kovár, 1977 and Hippodamia variegata (Goeze, 1777) have two or three generations in spring and one in autumn.

Considering the above, we initiated the present research to accomplish four goals: (1) Study the life cycles and abundance of pest aphids in an orchard in Algeria from January to June, the period when they are most abundant and destructive. (2) Compare the flight periods of several species of aphids belonging to three life-history groups: heteroecious species $(\mathrm{H})$, monoecious species living on trees (MT) and monoecious species living on herbaceous plants (MH), (3) Compare the flight periods of aphids with that of several ladybeetle (Coccinellidae) predators, (4) Test different sampling methods to determine which is best for capturing the different species of aphids and coccinellids.

\section{MATERIAL AND METHODS}

\section{Study site}

This study was carried out in an orchard at the experimental station of the Faculty of Nature and Life Sciences of the University of Blida, located $7 \mathrm{~km}$ east of Blida (longitude: $2^{\circ} 45^{\prime} \mathrm{E}$, latitude: $36^{\circ} 35^{\prime} \mathrm{N}$ ) in northern Algeria, which is in the foothills of the Blidean Atlas Mountains, at an altitude of $260 \mathrm{~m}$. The coldest months are January and February with an average minimum temperature of $4.5^{\circ} \mathrm{C}$ and average maximum temperature of $21.3^{\circ} \mathrm{C}$, with the hottest months, July and August, with an average maximum temperature of $37.1^{\circ} \mathrm{C}$ and average minimum temperature of $21.2^{\circ} \mathrm{C}$ (National Agency of Hydraulic Resources in Soumaa: 1994-2011). The ombrothermic diagram for 1994-2001 identifies two contrasting periods: a 7-month cool and wet season from October to April and a 5-month warm and dry season from May to September.

The orchard covered an area of about 1.5 ha and was planted with citrus, apple, pear, plum, apricot, peach and pomegranate trees. The herbaceous flora was diverse and included species of crop-adventitious annual weeds, which grow mainly in spring and dry out in mid-summer, such as: Stellarietea mediae (BraunBlanquet, 1921) Tüxen, Lohmeyer \& Preising in Tüxen $1950 \mathrm{em}$. Schubert in Schubert, Hilbig \& Klotz, 1995 (Sonchus oleraceus, Solanum nigrum, Sinapis arvensis subsp. arvensis), Onopordetea acanthii subsp. acanthii Braun-Blanquet, 1964 em. Julve, 1993 (Malva sylvestris, Silybum marianum, Melilotus albus, Echinops spinosus and Onopordum macracanthum) (Julve, 1998).

We identified the host plants of each of the species of aphids based on our own experience and by reference to the relevant literature (Turpeau et al., 2013). Our identifications usually matched those recorded in the literature. However, in Europe, the aphid Hyperomyzus lactucae (L., 1758) is heteroecious, alternat- ing between Ribes and Lactuceae (Turpeau et al., 2013), but in the orchard studied, it appears to be monoecious on Asteraceae.

\section{Methods}

To sample flying aphids and coccinellids, we set round plastic basins (tubs) filled 2/3 with soapy water as traps to catch and drown these insects. The basins were $16.5 \mathrm{~cm}$ in diameter and 8.5 $\mathrm{cm}$ deep. We used basins of three colours (yellow, green and orange) and set them at two heights (ground level and $1.5 \mathrm{~m}$ above the ground). The upper position was chosen because it is below the boundary layer for aphid flight (Taylor, 1974). Traps were set in a multi-varietal plot of fruit trees. At the centre of the plot, we set up three trapping sites in the form of a triangle, 20 meters from each other. At each site there were six traps ( 3 colours and 2 heights), which provided 3 replicates of each colour-height combination and 18 traps in operation continually from January to June, 2011. Water was renewed once a week during the cool period and every 3 to 4 days during hot period. The aphids and ladybirds collected weekly were kept in $70 \%$ alcohol, until identified to species and the number recorded. The species of aphids were identified using their morphological characters (Müller, 1976; Taylor, 1980; Jacky \& Bouchery, 1982; Remaudière et al., 1985; Heie, 1986; Leclant, 1999). Ladybirds were identified using Iablokoff-Khnzorian (1982) and Majerus \& Kearns (1989). The nomenclature of Aphididae and Coccinellidae was updated following Favret (2014) and Coutanceau (2009), respectively.

\section{Data analysis}

We analyzed data using one-way ANOVA, followed by Tukey's test when there were more than two categories. To assess the effect of each parameter on the numbers of aphids caught, we performed Kruskal-Wallis tests. The differences were considered as significant for p-values less than $5 \%$, and only marginally significant for $p$-values $\leq 8 \%$.

The phenology of the aphid and ladybird populations was assessed by calculating the Barycenter of abundance for each species, i.e., the date with the highest probability of catching a particular species (see Guendouz-Benrima et al., 2011). Briefly, this was calculated for species $\mathrm{j}$ using the formula:

$\operatorname{BSL}(\mathrm{j})=\Sigma\left(\mathrm{Ni}^{*}\right.$ abundance $\left.\mathrm{j}\right) / \Sigma($ abundance_j $)$

with $\mathrm{Ni}=$ number of the month (from $1=$ January to $6=$ June), and abundance $j=$ abundance of the species $j$ in the corresponding month.

Correspondence Analyses (CA) of the abundances of aphids and Coccinellidae were carried out to determine their temporal relationships. All the analyses were done using PAST 2.17 (Hammer et al., 2001).

\section{RESULTS}

\section{Abundance and species richness of the aphids caught by the different colored traps}

During the six months of trapping, 2145 aphids belonging to 17 taxa were captured (Table 1). The four most abundant species were: Brevicoryne brassicae (L., 1758), Aphis gossypii Glover, 1877, A. spiraecola and Hyalopterus pruni (Geoffroy, 1762), which made up around $56 \%$ of the total number of individuals caught. Another three species made up around 24\% [A. fabae, A. umbrella (Börner, 1950), and Uroleucon sonchi Geoffroy, 1762], and a third group of 10 less frequent species made up about $20 \%$ of the total catch. Analysis of the numbers, caught by the traps of different colours, using Tukey's test, indicate that more were caught 


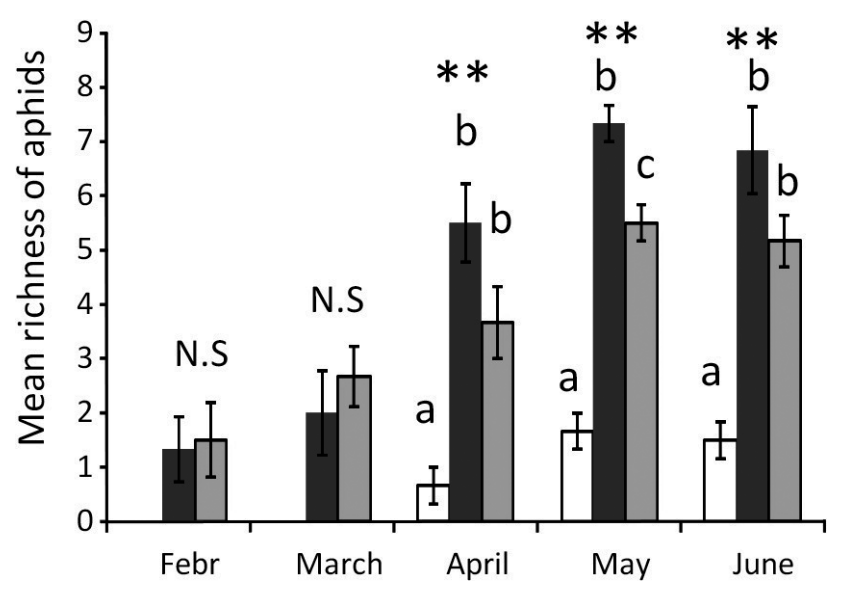

Fig. 1. Temporal changes in the mean species richness of aphids in three groups that differ in terms of their life cycles. Variations in mean species richness ( \pm standard errors). Symbols: White boxes - monoecious living on trees; dark grey boxes heteroecious species; light grey boxes - monoecious living on herbaceous plants. Different letters correspond to significant differences within months (ANOVAs). ${ }^{* *} \mathrm{p}<0.01,{ }^{*} \mathrm{p}<0.05$, N.S. $-p>10 \%$, not significant.

by yellow coloured than green traps $(p=0.050)$, and the number caught by the orange coloured traps did not differ from that caught by the two other coloured traps $(p>0.30)$. Similarly, traps set at $1.5 \mathrm{~m}$ above the ground caught more than $75 \%$ of total number of aphids caught.

Kruskal-Wallis tests of the catches of each species of aphid (Table 1) revealed that most varied significantly, at least marginally, from month to month, except those of H. lactucae and Capitophorus horni (Börner, 1931). The height of the trap also affected the numbers caught of most species, except Aphis punicae Passerini, 1860, H. pruni,

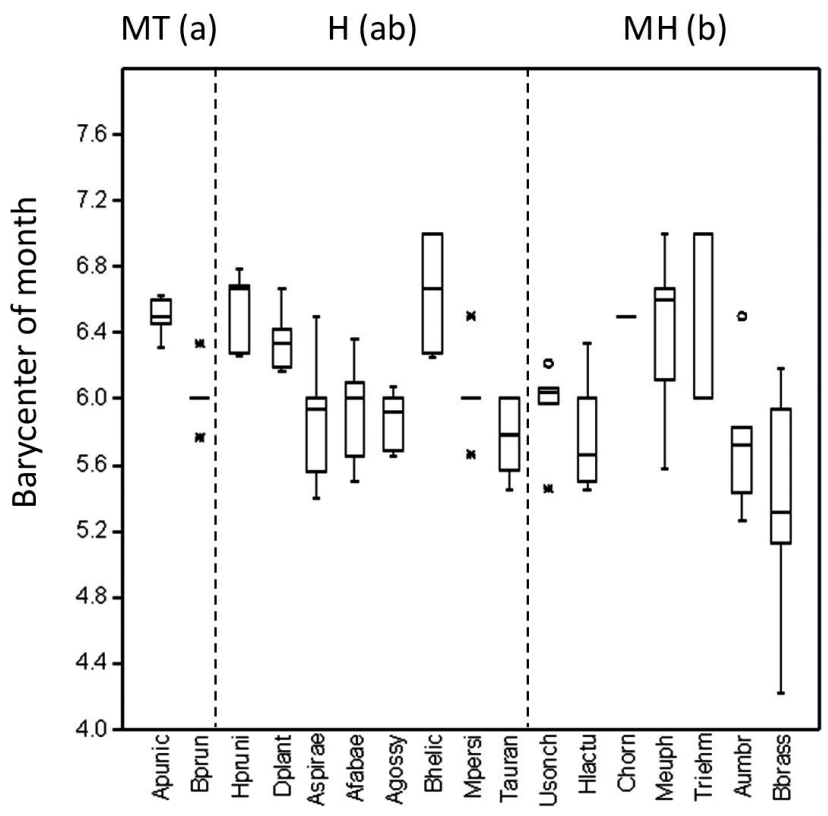

Fig. 2. Phenology (Barycenter) of each species of aphid. The different groups are separated by a dashed line. The divisions of months are expressed as decimals, e.g. mid-May is 5.5. The different letters in brackets for each group of species indicate whether they differ significantly (Kruskal-Wallis, $p=0.05$ ). Abbreviations: Aphis spiraecola - Aspirae, Aphis fabae - Afabae, Aphis gossypii - Agossy, Aphis umbrella - Aumbr, Aphis punicae - Apunic, Brevicoryne brassicae - Bbrass, Brachycaudus helichrysi - Bhelic, Brachycaudus prunicola - Bprun, Capitophorus horni - Chor, Dysaphis plantaginea - Dplant, Uroleucon sonchi - Usonch, Hyperomyzus lactucae - Hlactu, Hyalopterus pruni - Hpruni, Macrosiphum euphorbiae - Meuph, Myzus persicae - Mpersi, Therioaphis riehmi - Triehm, Toxoptera aurantii - Tauran.

TABLE 1. Abundances of aphid species caught by water traps of different colours set at different heights above the ground. Abbreviations: MT - monoecious on trees; $\mathrm{H}$ - heteroecy; $\mathrm{MH}$ - monoecious on herbaceous plants; $\mathrm{Y}$ - yellow, $\mathrm{G}$ - green, $\mathrm{O}$ - orange; $\mathrm{El}$ - trap set $1.5 \mathrm{~m}$ above the ground; Gl - basin set at ground level; Month - effect of month on catches (Kruskal-Wallis test, p-value); Height effect of height of trap above the ground on catches (Kruskal-Wallis test, p-value); Colour - effect of the colour of the traps on catches (Kruskal-Wallis test, p-value). The underlined p-values indicate marginal but non-significant differences.

\begin{tabular}{lcccccccccc}
\hline Aphid species & Cycle & YEl & YGl & GEl & GGl & OEl & OGl & Month & Height & Colour \\
\hline Aphis punicae Passerini, 1860 & MT & 29 & 10 & 11 & 0 & 8 & 2 & 0.001 & $\underline{0.150}$ & $\underline{0.333}$ \\
Brachycaudus prunicola (Kaltenbach, 1843) & MT & 13 & 3 & 4 & 0 & 7 & 1 & 0.009 & 0.013 & $\underline{0.400}$ \\
Hyalopterus pruni (Geoffroy, 1762) & $\mathrm{H}$ & 83 & 16 & 14 & 3 & 86 & 23 & $<0.001$ & $\underline{0.318}$ & $\underline{0.367}$ \\
Dysaphis plantaginea (Passerini, 1860) & $\mathrm{H}$ & 31 & 3 & 6 & 0 & 12 & 3 & 0.004 & 0.049 & $\underline{0.474}$ \\
Aphis gossypii Glover, 1877 & $\mathrm{H}$ & 113 & 29 & 45 & 2 & 128 & 9 & 0.061 & $<0.001$ & 0.357 \\
Aphis spiraecola Patch, 1914 & $\mathrm{H}$ & 184 & 30 & 29 & 8 & 34 & 10 & 0.024 & 0.004 & $\underline{0.089}$ \\
Aphis fabae Scopoli, 1763 & $\mathrm{H}$ & 80 & 11 & 36 & 5 & 61 & 21 & 0.023 & 0.001 & $\underline{0.524}$ \\
Toxoptera aurantii (B. de Fonscolombe, 1841) & $\mathrm{H}$ & 40 & 7 & 23 & 3 & 7 & 1 & 0.062 & 0.002 & $\underline{0.101}$ \\
Brachycaudus helichrysi (Kaltenbach, 1843) & $\mathrm{H}$ & 24 & 2 & 11 & 0 & 3 & 1 & 0.016 & 0.012 & $\underline{0.606}$ \\
Myzus persicae (Sulzer, 1776) & $\mathrm{H}$ & 8 & 3 & 3 & 3 & 9 & 2 & $<0.001$ & $\underline{0.148}$ & $\underline{0.734}$ \\
Brevicoryne brassicae (Linnaeus, 1758) & $\mathrm{MH}$ & 138 & 25 & 103 & 15 & 37 & 58 & 0.027 & 0.031 & $\underline{0.803}$ \\
Hyperomyzus lactucae (Linnaeus, 1758) & $\mathrm{MH}$ & 20 & 3 & 7 & 3 & 2 & 3 & $\underline{0.086}$ & 0.065 & $\underline{0.255}$ \\
Macrosiphum euphorbiae (Thomas, 1878) & $\mathrm{MH}$ & 9 & 3 & 19 & 1 & 5 & 4 & 0.005 & 0.036 & $\underline{0.784}$ \\
Aphis umbrella (Börner, 1950) & $\mathrm{MH}$ & 61 & 11 & 23 & 2 & 26 & 41 & 0.051 & 0.032 & $\underline{0.066}$ \\
Therioaphis riehmi (Börner, 1949) & $\mathrm{MH}$ & 12 & 3 & 1 & 0 & 0 & 3 & 0.053 & $\underline{0.587}$ & $\underline{0.312}$ \\
Uroleucon sonchi Geoffroy, 1762 & $\mathrm{MH}$ & 31 & 26 & 24 & 14 & 22 & 31 & $<0.001$ & $\underline{0.523}$ & $\underline{0.817}$ \\
Capitophorus horni (Börner, 1931) & $\mathrm{MH}$ & 4 & 0 & 0 & 0 & 2 & 0 & $\underline{0.395}$ & 0.035 & 0.328 \\
\hline
\end{tabular}



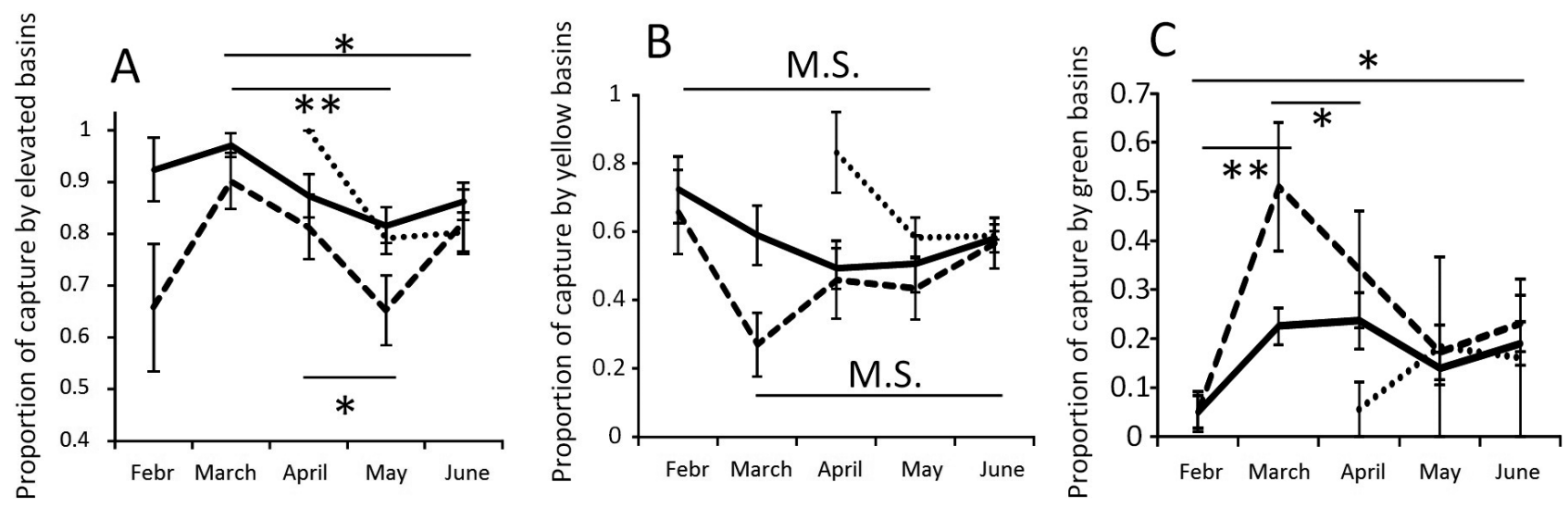

Fig. 3. Variations in the attractivity of traps of different colours to the aphids in the 3 groups of aphids with different life cycles. A - proportion of the aphids caught by high traps; B - proportion caught by yellow traps; C - proportion caught by green traps. Dotted lines - monoecious species living on trees; solid lines - heteroecious species; dashed lines - monoecious species living on herbaceous plants. Standard errors are indicated. The significance of the differences between months was determined using Kruskal-Wallis tests: $* * \mathrm{p}<0.01, * \mathrm{p}<0.05$, M.S. $-\mathrm{p}=0.08$, marginally significant.

Myzus persicae (Sultzer, 1776), Terioaphis riehmi (Börner, 1949), and U. sonchi. Trap colour had no significant effect on the number of aphids caught at the species level.

\section{Aphid flight phenology - monthly variations in the numbers of aphids of the three different life cycle groups caught by the traps}

We compared the monthly catches of aphids of the three different life cycle groups (H, MH, and MT). For heteroecious species $(\mathrm{H})$ and those living on herbaceous plants $(\mathrm{MH})$, catches increased from February to June. In contrast, the species richness of the tree-living aphids (MT) was zero in February and March, and then appears to increase but only two species were caught from April (Fig. 1). If we compare the catches for each month, the species richness of tree-living species is lower than that recorded for the two other groups of species in every month. The species richness of heteroecious species is greater than that for the two other groups from April to June.

The different species of aphids peaked in abundance between the second week of May and mid-June (Fig. 2). The variability within groups is not homogeneous, as the largest range in Barycentres was recorded for the species that are monoecious on herbaceous plants. In the $\mathrm{MH}$ group, $B$. brassicae is the earliest species caught (median in the sec-
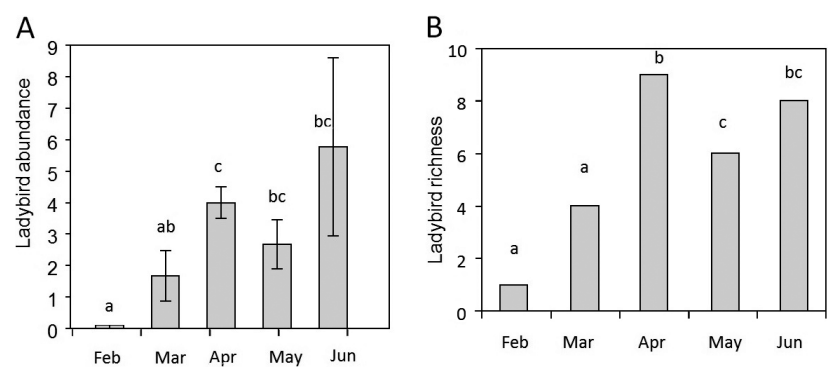

Fig. 4. The total number and number of species of coccinellids caught each month. A - the mean total number caught each month; B - the mean number of species caught each month. Different letters indicate significant differences (Bootstrap method). ond week of May) and Macrosiphon euphorbiae (Thomas, 1878) one of the latest (median in mid-June). If numbers caught is analyzed in terms of their life-cycles, it appears that the MT group are caught about 10 days significantly later than the $\mathrm{MH}$ group $(\mathrm{p}=0.05$, Kruskal-Wallis test) and the Barycentre for the $\mathrm{H}$ group did not differ from those of the other two groups.

\section{Variation in the attractiveness of the different coloured traps}

As for the catches of the water traps set at the two different heights, the three aphid groups vary in parallel, with a significant peak in March and a low in May, ending with a sub-equal proportions of the three groups in June (Fig. 3A). Lower proportions of the species in the $\mathrm{MH}$ group were caught by the high traps than of the other groups. Conversely, a higher proportion of species in the MT group was captured in April at $1.5 \mathrm{~m}$ than of the other groups.

As for the proportion caught by yellow traps, there were marginally significant differences $(p=0.08)$ between February and May, and between March and June aphids (Fig. 3B). The values for the MH group are regularly lower than those for other groups, principally in March when it is less than 0.3. A higher proportion of species of the MT group

TABLE 2. Barycenters of the numbers of the different coccinellids caught by the traps each month.

\begin{tabular}{lllllll}
\hline & \multicolumn{4}{c}{ Feb Mar AprMay June $\begin{array}{c}\text { Bary- } \\
\text { center }\end{array}$} \\
\hline Hippodamia variegata (Goeze, 1777) & 0 & 3 & 4 & 0 & 0 & 3.57 \\
Pullus subvillosus (Goeze, 1777) & 0 & 6 & 7 & 3 & 2 & 4.06 \\
Scymnus sp. & 0 & 0 & 3 & 0 & 1 & 4.50 \\
Scymnus marginalis (Rossi, 1794) & 0 & 0 & 4 & 3 & 2 & 4.78 \\
Pullus impexus (Mulsant, 1850) & 0 & 0 & 3 & 0 & 2 & 4.80 \\
Scymnus frontalis (Fabricius, 1787) & 0 & 0 & 3 & 4 & 2 & 4.89 \\
Nephus sp. & 0 & 0 & 3 & 4 & 4 & 5.09 \\
Coccinella algerica Kováŕ, 1977 & 1 & 1 & 3 & 7 & 13 & 5.20 \\
Scymnus apetzi Mulsant, 1846 & 0 & 5 & 6 & 3 & 26 & 5.25 \\
\hline
\end{tabular}




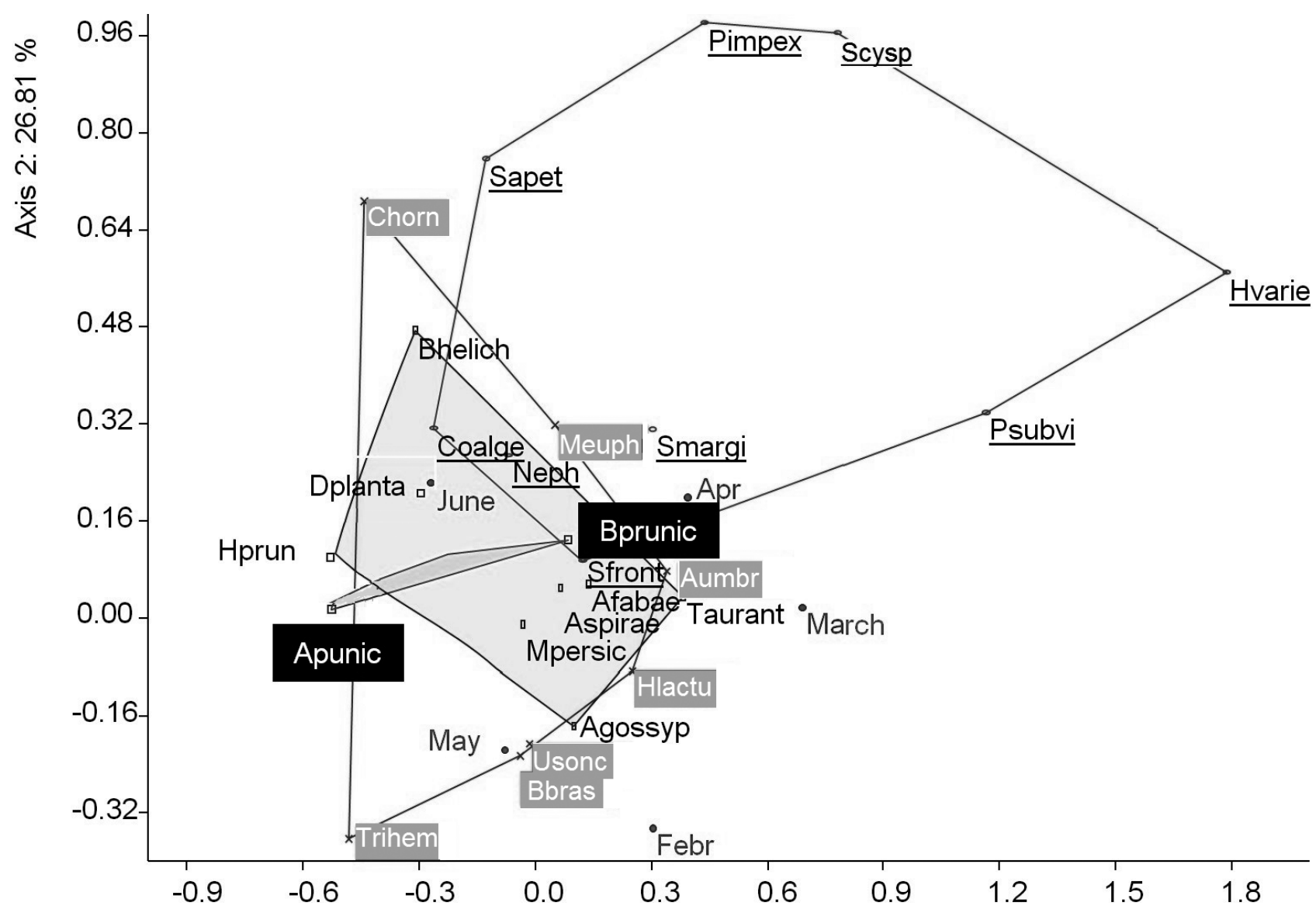

Fig. 5. The relative timing of the activity of aphids and ladybirds based on trap catches displayed in two-dimensional graphical form based on a correspondence analysis. Underlined codes - ladybird species; white letters on black background - aphids of group MT (dtto for grey envelope); black letters without a background - aphids of group H (dtto for a light grey envelope); white letters on grey background - aphids of group MH. Abbreviations for aphids: Aphis spiraecola - Aspirae, Aphis fabae - Afabae, Aphis gossypii - Agossy, Aphis umbrella - Aumbr, Aphis punicae - Apunic, Brevicoryne brassicae - Bbras, Brachycaudus helichrysi - Bhelic, Brachycaudus prunicola - Bprun, Capitophorus horni - Chorn, Dysaphis plantaginea - Dplanta, Uroleucon sonchi - Usonc, Hyperomyzus lactucae - Hlactu, Hyalopterus pruni - Hprun, Macrosiphum euphorbiae - Meuph, Myzus persicae - Mpersic, Therioaphis riehmi - Triehm, Toxoptera aurantii - Taurant. Abbreviations for ladybirds: Coccinella algerica - Coalge, Hippodamia variegata - Hvarie, Nephus sp. - Neph, Pullus impexus - Pimpex, Pullus subvillosus - Psubvi, Scymnus apetzi - Sapet, Scymnus frontalis - Sfront, Scymnus marginalis - Smargi, Scymnus sp. - Scysp.

were caught in April than of the other two groups. As for green traps, the higher proportion caught in March is significantly different from the values for February and April. The catches of the $\mathrm{MH}$ and $\mathrm{H}$ groups vary in parallel with a peak in March, which is most pronounced for the $\mathrm{MH}$ group (Fig. 3C).

\section{Temporal activity of Coccinellidae}

The abundance (Fig. 4A) and species richness of coccinellid community varied in parallel (Fig. 4B): with the first peak in April followed by a decrease in May and a second peak in June.

The monthly Barycenters indicate the relative precocity of the different species (Table 2). Three groups can be defined: the April group is the largest with 5 species [Pullus subvillosus (Goeze, 1777), Scymnus sp., Scymnus marginalis (Rossi, 1794), Pullus impexus (Mulsant, 1850), and Scymnus frontalis (Fabricius, 1787)]; the second group is associated with May and contains 3 species (Nephus sp.,
Coccinella algerica Kovář, 1977 and Scymnus apetzi Mulsant, 1846) and the March group includes only Hippodamia variegata (Goeze, 1777). It should be noted that the first ladybird regularly recorded each year is Coccinella algerica.

\section{Coincidence in the temporal activities of aphids and ladybirds}

Based on the projection of results for the aphid and ladybird species on the F1F2 plane of the Correspondence Analysis, it appears that these two groups of insects fly at different periods of the year (Fig. 5). Most ladybirds begin flying earlier than aphids. However, the temporal variation in the flight activity of Coccinella algerica, Scymnus frontalis and Nephus sp. is the closest to that of the aphids. The flight activity of Scymnus apetzii and Scymnus marginalis occurs much earlier than that of most aphids. The flight activity of the earliest ladybirds (H. variegata, Pullus sub- 
villosus, and Scymnus sp.) occurs very much earlier than that of the aphids.

If we compare these results with those for the aphids in the three life cycle groups, their flight activities overlap, but that of the monoecious group on herbaceous plants extends over a longer period than that of the other two groups of aphids.

\section{DISCUSSION}

In this study we recorded the flight activity of aphids and their coccinellid predators in an orchard in northern Algeria. Specifically, we compared species richness, temporal distribution and abundance of aphids and coccinellids in an orchard containing many different kinds of fruit trees during the first half of a year (January to July). We also determined the synchrony between the flight activity of aphids and their coccinellid predators. They both occur in similar habitats and were notably abundant in herbaceous and arborescent strata as well as in crops. Finally, we compared catches of water traps of three different colours set at two heights.

\section{Ecological features of the three life cycle groups of aphids}

Of the 17 aphid taxa caught by the traps, there were 8 heteroecious species, i.e. about half the diversity. This percentage is high given that the global percentage for Aphididae is less than 15\% (Kim et al., 2011). In Belgium, heteroecious species make up around $34 \%$ of all aphid species if the species alternating between Ribes or Rubus/herbaceous species are excluded (Yattara \& Francis, 2013). This richness in host alternating species could be due to either the Mediterranean environment, or to the rich herbaceous flora at the study site, but this needs be tested by carrying out larger scale studies. However, it is most likely the Mediterranean environment as (i) we caught two tree-living species ( $11 \%$ of all the species caught), which is similar to the general statistics for this family (around 14\%); and (ii) the remaining 7 species caught during this study are monoecious on herbaceous plants (41\%), which is low compared to the $71 \%$ in this category recorded for the whole family. This study aimed to determine whether the aphids in each of the 3 groups differed from those in the other groups in terms of the attractiveness of different colours and the height above the ground at which they fly and when they fly.

Our results indicate the number of aphids caught by the traps varied between months, at both the species and group levels. There is a peak in species richness and abundance in May, about one month earlier than recorded in Belgium (Yattara \& Francis, 2013). The difference in the phenology of aphids in Europe and Algeria is obviously due to the warmer climate in Northern Africa (for review, see Hullé et al., 2010). In this study, the tree-living species began flying later than those of the other two groups, but the flight periods of several species of heteroecious aphids were also late. The precocity of most of the aphids living on herbaceous plants is most likely due to the earlier development of the herbaceous flora relative to that of the leaves of the trees. In the orchard, many species of herbaceous plants sprouted in February whereas bud burst of most of the fruit trees did not occur until the end of March. However, we recorded great variability between the monoecious species living on herbaceous plants, which is most likely because the different families of plants have different phenologies. $B$. brassicae is the most precocious, which is mainly due to its living on Sinapis arvensis that is present even in winter. It is also well known that in North Africa species of Lactuceae, the host plants of $U$. sonchi, appear before species of Cardueae, the host plants of Capitophorus horni (Kamel et al., 2011). Among the species in the heteroecious group, winged Brachycaudus helichrysi (Kaltenbach, 1843) are caught about two weeks after the other species, mainly because their herbaceous host plants belong to the Cardueae. The phenology of plants is not the only factor determining the temporal variation in the numbers of aphids caught, as the concentrations of secondary metabolites in the tissues of the plants also have an important role (Mostefaoui et al., 2014), which needs to be confirmed for herbaceous plants.

In terms of trap height, most aphids were caught by traps positioned $1.5 \mathrm{~m}$ above the ground, which is similar to the findings of Hullé et al. (1993). The numbers caught by the traps is different in the different seasons with the proportion of aphids caught by the high traps peaking significantly in March, a period when aphids are colonizing their host plants. For species living on herbaceous plants, these peak captures could indicate the timing of the colonizing of the orchard from adjacent areas, but this needs to be confirmed. It could also be recording the spring flight of host alternating aphids, which leave their primary host and colonize their secondary hosts, which are, herbaceous species. The proportion of aphids caught by traps is lowest in May, particularly so for those species that live on herbaceous plants. They remain on the same herbaceous plants until the end of the season when they fly back to their primary host plants, i.e. trees. It is possible that these species mainly completed their life cycle in the orchard, with few aphids coming from outside the orchard. These speculations need to be treated with caution, as Hullé et al. (1993) demonstrate that the proportion of captures by traps set at different heights is site-dependent.

In this study, yellow traps caught more aphids overall, as previously recorded by other authors (Döring \& Chittka, 2007 for review). This is especially true in February for heteroecious species and in April for monoecious species living on trees. These temporal changes are also illustrated by a significant peak in March during which the green traps caught nearly 50\%, particularly monoecious species living on herbaceous plants. This could be due to the greater sensitivity of aphids to contrasts in colour than particular wavelengths of light (Döring \& Chittka, 2007). Accepting this, the relatively high attractiveness of green traps for species of aphids living on herbaceous plants in March is possibly due to the contrast between the colour of the trap and the ground, which at that time is still only half covered with herbaceous vegetation. During the subsequent months, vegetation cover increases, resulting in greater 
brightness and a more yellow colour, which is highly attractive for aphids (Moericke, 1955). This is particularly true for tree-living species, which prefer this colour when they disperse to other trees. In June, in northern Algeria, the herbaceous flora begins to dry out and loose its overall green colour, so the contrast between the foliage of trees and the ground changes. These hypotheses, however, need to be tested.

In this study, aphids with the three types of life cycles differed behaviourally and ecologically. Much more work is needed to determine the reason for the temporal changes in the attractiveness of different colours for different species of aphids, in particular the effect of ground cover on the attractiveness of different colours. The temporal variations in the distribution of the different species of aphids on the vegetation need to be determined in order to understand the micro-migrations at the site scale, which will help interpret the temporal variations in catches of the traps set at different heights.

\section{Coincidence between flight activities of ladybirds and aphids}

The early catches of aphidophagous ladybirds are of individuals arriving in the orchard from overwintering sites, under tree bark and stones, in mountain forests and foot hill fallow lands, and litter at the base of grass tufts (Savoiskaya, 1966). We recorded 9 species of ladybirds and except for Nephus sp., all feed on aphids. This represents a third of the 24 aphidophagous species recorded in Algeria (Saharaoui \& Gourreau, 2000; Saharaoui et al., 2001; Saharaoui \& Hemptinne, 2009). If we compare the peak catches of the different species of aphids and ladybirds, the greatest species richness of aphids is in the second half of May, whereas there are two periods when the diversity of coccinellids is high, April and June. In the first period, the ladybirds are mainly Hippodamia variegata, Pullus subvillosus, Scymnus sp. and S. marginalis (Djazouli et al., 2009). These ladybirds feed on the first aphids to appear, the monoecious species living on herbaceous plants. During the second period, the ladybirds are mainly Coccinella algerica and S. apetzii, and other small-sized ladybirds, whose main prey are the late-season species of aphid that are monoecious and live on trees, the heteroecious species (Hyalopterus pruni and B. helichrysi) and the monoecious that live on herbaceous plants (C. horni, M. euphorbiae, and T. riehmi). As for the aphids, it would be informative to record the colonization and movements of ladybirds during the season at the scale of the orchard. There are very few studies of micro-movements by Algerian ladybirds, however, we can cite the case of Pullus subvillosus which completes its life cycle on a Citrus tree on the Mitidja plain, whereas Hippodamia variegata reproduces on herbaceous plants or bushes (Saharaoui \& Hemptinne, 2009).

In summary, it is clear that the principal group of aphids subject to predation by Coccinellidae is the tree-living group. Although the aphids living on herbaceous plants are attacked by ladybirds during two periods each season, depending on the year, one of these attacks can be reduced, which is to the advantage of some of the species of aphids that are monoecious on herbaceous plants. The feeding activity of coccinellids varies with temperature, with the temperature threshold of $11^{\circ} \mathrm{C}$ for Coccinella septempunctata L., 1758 feeding on Acyrthosiphon pisum Harris, 1776 (Harrington et al., 2001). Below this temperature, the aphid's reproduction rate exceeds that of the ladybird, and the reverse is true for temperatures above this threshold. Threshold temperatures should be studied for all possible aphid/ladybird interactions. We predict that this critical temperature is low in the case of Coccinella algerica and Scymnus marginalis, which fly early and feed on aphids infesting adventitious plants.

\section{CONCLUSIONS}

There are marked differences between the aphids in the three groups, in terms of when in the season the maximum numbers were caught by water traps. Interestingly, the attractiveness of the different colored traps varied during the season, possibly because of the change in the contrast between the colour of the host plants and their environment, which dries out at the end of spring. The three groups of aphids do not seem to be subject to similar levels of predation by ladybirds, but this needs to be verified. In addition, a similar study in late summer and autumn is likely to provide useful information as the populations of aphids and ladybirds at that time of a year are very low.

ACKNOWLEDGEMENTS. We thank D. Whitman (Illinois State University) for his help in editing and correcting the English.

\section{REFERENCES}

Blackman R.L. \& Eastop V.F. 1994: Aphids on the World's Trees: An Identification and Information Guide. CABI, Wallingford, 987 pp.

Blackman R.L. \& Eastop V.F. 2008: Aphids on the World's Herbaceous Plants and Shrubs. John Wiley \& Sons, Chichester, $1439 \mathrm{pp}$.

Blackman R.L. \& Eastop V.F. 2012: Aphids on the World's Plants. An Online Identification and Information Guide. http:// www.aphidsonworldsplants.info/

Coutanceau J.P. 2009: Liste synonymique des Coléoptères Coccinellidae de France continentale et de Corse. - Harmonia 3: $3-14$.

Djazouli Z.E., Doumandi-Mitiche B. \& Petit D. 2009: Spatiotemporal variations of functional groups in a Populus nigra L. entomocenosis in the Mitidja plain (Algeria). $-C$. R. Biologies 332: 848-860.

DöRING T. \& ChITTKa L. 2007: Visual ecology of aphids - a critical review on the role of colours in host finding. - Arthr. Plant Inter. 1: 3-16.

Favret C. 2014: Aphid Species File. Version 5.0/5.0. http://Aphid. SpeciesFile.org

Guendouz-Benrima A., Doumandi Mitiche B. \& Petit D. 2011: Effects of weak climatic variations on assemblages and life cycles of Orthoptera in North Algeria. - J. Arid Environ. 75: 416-423.

Hammer O., Harper D.A.T. \& Ryan P.D. 2001: PAST version 1.39: Paleontological statistical software package for education and data analysis. - Paleontol. Electronica 4: 9 pp.

Harrington R., Fleming R.A. \& Woiwood I.P. 2001: Climate change impacts on insect management and conservation in 
temperate regions: Can they be predicted? - Agric. Forest Entomol. 3: 233-240.

HeIE O.E. 1986: The Aphidoidea (Hemiptera) of Fennoscandia and Denmark. III. Family Aphididae: Subfamily Aphidinae. Fauna Entomologica Scandinavica, Vol. 17. E.J. Brill/Scandinavian Science Press, Leiden, New York, Köln, 242 pp.

Hullé M., Vessier E., Robert Y. \& Rouzé-Jouan J. 1993: Étude de l'influence de la hauteur de piégeage sur les captures de pucerons ailés en différents sites et sur plusieurs années. Agronomie 13: 615-629.

Hullé M., Ceeur d'Acier A., Bankhead-Dronnet S. \& HarRINGTON R. 2010: Aphids in the face of global changes. - C.R. Biologies 333: 497-503.

IABLoKoff-Khnzorian S.M. 1982: Les Coccinelles: Coléoptères Coccinellidae, Tribu Coccinellini des Régions Paléarctiques et Orientales. Boubée, Paris, 568 pp.

Ives A.R., Kareiva P. \& Perry R. 1993: Response of a predator to variation in prey density at three hierarchical scales lady beetles feeding on aphids. - Ecology 74: 1929-1938.

JACKy F. \& Bouchery Y. 1982: Atlas des Formes Ailées des Espèces Courantes de Pucerons. INRA, Colmar, 48 pp.

Julve P. 1998: ff. Baseveg. Index Phytosociologique Synonymique de la Végétation de la France. Programme Catminat. http://perso.wanadoo.fr/philippe.julve/catminat.htm [Accessed August, 2010].

Kamel M.B.H., RebHi R. \& Ommezine A. 2011: Habitats et proies de Coccinella algerica Kovar dans différentes régions côtières de la Tunisie. - Entomol. Faun. Faun. Entomol. 63: 35-45.

KIM H., LeE S. \& JANG Y. 2011: Macroevolutionary patterns in the Aphidini aphids (Hemiptera: Aphididae): Diversification, host association, and biogeographic origins. - PLOS ONE 6: e24749.

KIRK W.D.J. 1984: Ecologically selective coloured traps. - Ecol. Entomol. 9: 35-41.

Leclant F. 1999: Les Pucerons des Plantes Cultivées. Clefs d'Identification, Cultures Maraichères II. INRA/ACTA, Paris, $98 \mathrm{pp}$.

Majerus M. \& Kearns P. 1989: Ladybird. Naturalists' Handbooks 10. The Richmond Publishing, Slough, 103 pp.

Moericke V. 1955: Über das Verhalten phytophager Insekten während des Befallsfluges unter dem Einfluß von weißen Flächen. - Z. Pflanzenkr. Pflanzensch. 62: 588-593.
Mostefaoui H., Allal-Benfekim L., Duazouli Z.E., Petit D. \& SALAdIN G. 2014: Why the aphid Aphis spiraecola is more abundant on clementine tree than A. gossypii? - C. R. Biologies 337: 123-133.

MÜLLER F.P. 1976: Mszyce - szkodniki roślin. Terenowy klucz do oznaczania. In: Klucze do Oznaczania Bezkręgowców Polski. Vol. 2. Polish Academy of Sciences, Warszawa, 119 pp.

Remaudière G. \& Remaudière M. 1997: Catalogue des Aphididae du Monde (Homoptera: Aphidoidea). INRA, Paris, 478 pp.

Remaudière G., Eastop V.F. \& Autrique A. 1985: Distribution des aphides de la région éthiopienne. In Remaudière G. \& Autrique A. (eds): Contribution à l'Ecologie des Aphides Africains. FAO, Rome, pp. 76-93.

Saharaoui L. \& Gourreau J.M. 2000 : Les coccinelles d'Algérie: inventaire et régimes alimentaires (Coleoptera, Coccinellidae). - Rech. Agron. 6: 11-27.

Saharaoui L. \& Hemptinne J.L. 2009: Dynamique des communautés des coccinelles (Coleoptera: Coccinellidae) sur agrumes et interactions avec leurs proies dans la région de Rouïba (Mitidja orientale) Algérie. - Ann. Soc. Entomol. Fr. 45: 245-259.

Saharaoui L., Gourreau J.M. \& Iperti G. 2001: Étude des paramètres bioécologiques de quelques coccinelles aphidophages d'Algérie (Coleoptera, Coccinellidae). — Bull. Soc. Zool. Fr. 126: 351-373.

SAVOISKAYA G.I. 1966: Hibernation and migration of coccinellids in south-eastern Kazakhstan. In Hodek I. (ed.): Ecology of Aphidophagous Insects. Academia, Prague, pp. 139-142.

TAYLOR L.R. 1974: Insect migration, flight periodicity and the boundary layer. - J. Anim. Ecol. 43: 225-238.

TAYLOR L.R. 1980: Aphid Forecasting and Pathogens and a Handbook for Aphid Identification. Euroaphid, Rothamsted Experimental Station, Harpenden, 163 pp.

Turpeau E., Hullé M. \& Chaubet B. 2013: Encyclop'Aphid. https://www6.inra.fr/encyclopedie-pucerons

Yattara A.A. \& Francis F. 2013: Impact des méthodes de piégeage sur l'efficacité de surveillance des pucerons: illustration dans les champs de pommes de terre en Belgique. - Entomol. Faun. Faun. Entomol. 66: 89-95.

Received June 24, 2014; revised and accepted March 23, 2015 Prepublished online May 15, 2015 